\title{
SISTEM PAKAR DIAGNOSA PENYAKIT GIGI MENGGUNAKAN METODE FORWARD CHAINING (STUDI KASUS: KLINIK GIGI DRG. TETRA ASMIRA TELUK KUANTAN)
}

\author{
Walhidayat $^{1}{ }^{*}$, Rizki Nanda ${ }^{1}$ \\ Program studi Sistem informasi Fasilkom UNILAK, Pekanbaru \\ Email:*walhidayat@unilak.ac.id
}

\begin{abstract}
The scientific field of computer information systems along with the times has its own role to provide alternative solutions for humans to help solve problems for various health complaints. Various methods - methods are designed to help patients with dental disease problems, in this case the researcher uses the forward chaining method to see the rules based on valuable information from experts (Drg. Tetra Asmira). A rule that is made to complete the forward chaining method with the appearance of a web-based application. The need for the application of the scientific field of computer information systems to help various fields of humanity here has the opportunity to continue to be developed using various available methods.
\end{abstract}

Keywords: dental expert system, forward chaining, expert system application

\begin{abstract}
Abstrak: Bidang keilmuan sistem informasi komputer seiring dengan perkembangan jaman telah memiliki peran tersendiri untuk memberikan alternatif solusi bagi manusia untuk membantu menyelesaikan permasalahan untuk berbagai keluhan kesehatan. Berbagai metode - metode dirancang untuk membantu pasien dengan masalah penyakit gigi, dalam hal ini peneliti menggunakan metode forward chaining untuk melihat rule yang didasarkan dari informasi yang bernilai dari pakarnya (Drg. Tetra Asmira). Rule yang di buat menyelesaikan untuk metode forward chaining dengan tampilan aplikasi berbasis web. Perlunya penerapan bidang keilmuan sistem informasi komputer untuk membantu berbagai bidang kemanusiaan disini memiliki peluang untuk terus dikembangkan dengan menggunakan berbagai metode yang tersedia.
\end{abstract}

Kata kunci: sistem pakar gigi, forward chaining, aplikasi sistem pakar

\section{PENDAHULUAN}

Pemanfaatan teknologi pada bidang kesehatan digunakan untuk meningkatkan pelayanan kesehatan yang lebih baik.
Pelaksana medis, khususnya dokter, saat ini masih sangat terbatas jika dibandingkan jumlah penduduk dunia, pekerjaan dokter menjadi berkali lipat dari seharusnya agar dapat melayani 
seluruh penduduk yang mengalami permasalahan dengan kesehatan. Sistem pakar yang merupakan cabang ilmu komputer juga dapat diterapkan dibidang kedokteran. Gigi adalah organ yang sangat penting dan sangat vital keberadaannya. Oleh karenanya kesehatan kondisi gigi sangatlah penting. Sebagian besar masyarakat indonesia, himbauan untuk periksa gigi enam bulan sekali lebih sering dianggap angin lalu, karna mungkin mereka lebih mementingkan kesehatan organ-organ tubuh yang lain. Padahal penyakit yang menyerang gigi dapat menimbulkan efek yang sangat berarti seperti misalnya masalah penampilan[1].

Penelitian ini menerapkan ilmu komputer dibidang kedokteran terutama untuk masalah penyakit gigi di Klinik Drg.Tetra Dona Asmira dengan menggunakan konsep sistem pakar. Sistem pakar merupakan suatu sistem berupa aplikasi komputer dimana komputer dibuat seakan-akan berpikir seperti orang pakar/ahli dalam bidangnya. Di Klinik Drg.Tetra Dona Asmira dokter gigi tidak setiap hari ada, akan tetapi banyak pasien yang datang hanya sekedar periksa gigi ataupun berobat. Sedangkan dokter tidak terlalu ada setiap hari, sehingga banyak pasien yang kecewa karna tidak dapat konsultasi langsung dengan dokter. Dari permasalahan tersebut penulis membuat aplikasi sistem pakar diagnosa penyakit gigi dengan tujuan untuk membantu mendiagnosa pasien.

\section{METODE}

Penelitian ini dilaksanakan berlokasi pada klinik Drg. Tetra Asmira, teluk Kuantan - Kuansing Riau. Dimana untuk mengambil informasi pakar untuk dijadikan sebagai basic rule dalam metode forward chaining penelitian ini peneliti membutuhkan informasi dari pakarnya langsung, yaitu Drg. Tetra Asmira yang membuka klinik Gigi.

Proses ini dapat dilihat pada diagram alir Gambar 1.

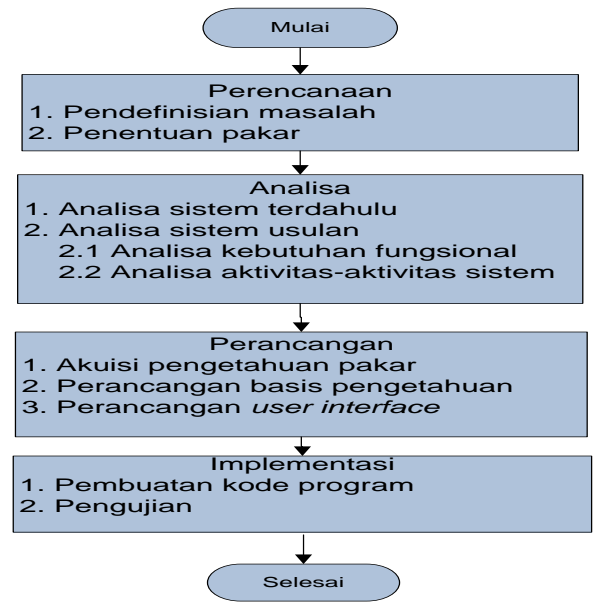

Gambar 1 Diagram Alir Penelitian

\section{HASIL DAN PEMBAHASAN}

Basis Pengetahuan

Basis pengetahuan adalah pengetahuanpengetahuan pakar yang berupa faktafakta, konsep, aturan, prosedur, dan 
DOI: https://doi.org/10.33330/jurteksi.v5i2.344

Available online at http://jurnal.stmikroyal.ac.id/index.php/jurteksi

hubungan di antaranya, yang telah direpresentasikan dalam bentuk yang dimengerti oleh system[2]. Basis pengetahuan dibutuhkan untuk memahami, dan memecahkan masalah yang dihadapi oleh sistem. Basis pengetahuan yang digunakan dalam penelitian ini adalah basis pengetahuan penyakit, basis pengetahuan gejala dan basis pengetahuan rule gejala dengan penyakit[3].

\section{a. Basis Pengetahuan Penyakit}

Basis pengetahuan penyakit berisi datadata penyakit gigi yang teridentifikasi sebanyak 9 penyakit. Seperti yang terlihat pada Tabel 3.1.

\section{Tabel 3.1 : Penyakit Gigi}

\begin{tabular}{ll}
\hline \multicolumn{1}{c}{ ID } & NAMA \\
PENYAKIT & PENYAKIT \\
\hline P01 & Karies Gigi \\
\hline P02 & Pulpitis \\
\hline P03 & Abses Gigi \\
\hline P04 & Abrasi Gigi \\
\hline P05 & Atrisi Gigi \\
\hline P06 & Erosi Gigi \\
\hline P07 & Gingivitis \\
\hline P08 & Periodonitis \\
\hline P09 & Fraktur \\
\hline
\end{tabular}

\section{b. Basis Pengetahuan Gejala Penyakit Gigi}

Basis pengetahuan penyakit gigi berisi data-data gejala penyakit gigi sebanyak 20 gejala. Seperti yang terlihat pada tabel 3.2 .

\section{Tabel 3.2 GejalaPenyakit Gigi}

\begin{tabular}{|l|l|}
\hline \multicolumn{1}{|c|}{ ID GEJALA } & NAMA GEJALA \\
\hline G01 & Gigi Berlubang \\
\hline G02 & Gigi Terasa Ngilu \\
\hline G03 & Terkadang Timbul Rasa Sakit \\
\hline G04 & Terkadang Sisa Makanan Masuk Ke Daerah Yang Berlubang \\
\hline G05 & Ada Bagian Gigi Yang Hilang \\
\hline G06 & Gigi Terasa Sakit \\
\hline G07 & Gusi Atau Pipi Bengkak \\
\hline G08 & Gigi Sakit Jika Makan / Minum Panas Atau Dingin \\
\hline G09 & Gigi Gonyang \\
\hline G10 & Demam \\
\hline G11 & Ada Bagian Gigi Yang Hilang / Terkikis \\
\hline G12 & Sering Menggosok Gigi dengan Tekanan Keras \\
\hline G13 & Bagian Email Gigi Terkikis \\
\hline G14 & Gigi Terlihat Tampak Lebih Menguning \\
\hline G15 & Bentuk Tepi Gigi Menjadi Tidak Teratur Dan Kasar \\
\hline G16 & Bagian Gusi Mudah Berdarah \\
\hline G17 & Bau Nafas Tidak Sedap \\
\hline G18 & Gusi Sakit Jika Disentuh \\
\hline G19 & Karang Gigi Banyak \\
\hline G20 & Merasakan Tidak Nyaman \\
\hline & \\
\hline
\end{tabular}


DOI: https://doi.org/10.33330/jurteksi.v5i2.344

Available online at http://jurnal.stmikroyal.ac.id/index.php/jurteksi

c. Basis Pengetahuan Rule Gejala dan Penyakit

Berisi tentang data hubungan antara gejala dengan penyakit, seperti yang terlihat pada tabel berikut.

Tabel 3.3 : Rule Gejala Dan Penyakit Gigi

\begin{tabular}{|c|c|c|c|c|c|c|c|c|c|}
\hline \multirow{3}{*}{$\begin{array}{l}\text { Kode } \\
\text { Gejala }\end{array}$} & \multicolumn{9}{|c|}{ Penyakit Gigi } \\
\hline & $\begin{array}{l}\text { Karies } \\
\text { Gigi }\end{array}$ & Pulpitis & $\begin{array}{l}\text { Abses } \\
\text { Gigi }\end{array}$ & $\begin{array}{l}\text { Abrasi } \\
\text { Gigi }\end{array}$ & $\begin{array}{l}\text { Atrisi } \\
\text { Gigi }\end{array}$ & $\begin{array}{l}\text { Erosi } \\
\text { Gigi }\end{array}$ & $\begin{array}{l}\text { Gingivi } \\
\text { tis }\end{array}$ & $\begin{array}{l}\text { Periodo } \\
\text { nitis }\end{array}$ & Fraktur \\
\hline & P1 & $\mathrm{P} 2$ & P3 & $\mathrm{P} 4$ & P5 & P6 & P7 & P8 & P9 \\
\hline G01 & $*$ & * & & & & & & & \\
\hline G02 & * & $*$ & $*$ & $*$ & * & $*$ & & & * \\
\hline G03 & * & & & & & & & & \\
\hline G04 & * & & & & & & & & \\
\hline G05 & * & $*$ & & & & & & & * \\
\hline G06 & & $*$ & $*$ & $*$ & & $*$ & * & $*$ & $*$ \\
\hline G07 & & $*$ & $*$ & & & & * & $*$ & \\
\hline G08 & & $*$ & & & & & & & \\
\hline G09 & & & $*$ & & & & & $*$ & * \\
\hline G10 & & & $*$ & & & & & & \\
\hline G11 & & & & $*$ & $*$ & & & & \\
\hline G12 & & & & * & & & & & \\
\hline G13 & & & & & $*$ & & & & \\
\hline G14 & & & & & & $*$ & & & \\
\hline G15 & & & & & & $*$ & & & \\
\hline G16 & & & & & & & $*$ & $*$ & \\
\hline G17 & & & & & & & $*$ & $*$ & \\
\hline G18 & & & & & & & $*$ & & \\
\hline G19 & & & & & & & & $*$ & \\
\hline G20 & & & & & & & & & $*$ \\
\hline
\end{tabular}

\section{Pengujian Sistem}

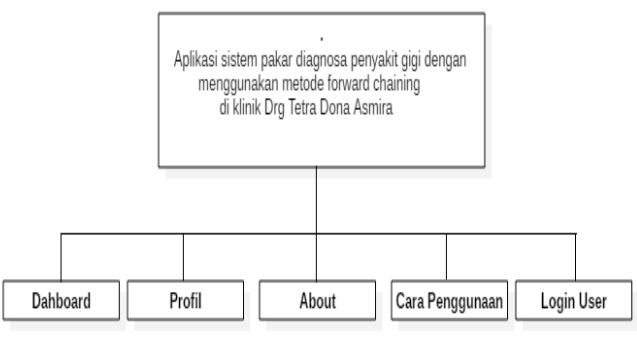

Gambar 3.2 Rancangan Aplikasi
Pengujian sistem ini dilakukan untuk menguji hubungan antara program aplikasi yang dibuat dengan elemen yang lain dalam sistem informasi. Adapun tujuan dari pengujian sistem ini adalah untuk memastikan semua elemen sistem sudah terhubung dengan baik. Berikut table pengujian black box admin dan user. 
DOI: https://doi.org/10.33330/jurteksi.v5i2.344

Available online at http://jurnal.stmikroyal.ac.id/index.php/jurteksi

Tabel 5.1 Black BoxTesting Halaman Admin

\begin{tabular}{|c|c|c|c|}
\hline No & Rancangan Proses & Hasil Yang Diharapkan & Hasil \\
\hline 1. & $\begin{array}{l}\text { Mengisi form login administrator dengan } \\
\text { memasukan username dan password dan klik } \\
\text { tombol login }\end{array}$ & $\begin{array}{l}\text { Masuk halaman utama } \\
\text { administrator }\end{array}$ & Sesuai \\
\hline \multirow{3}{*}{2.} & Mengisi form entri gejala dan klik simpan & $\begin{array}{l}\text { Data tersimpan data muncul di } \\
\text { data gejala }\end{array}$ & Sesuai \\
\hline & Klik menu edit gejala & Muncul form edit gejala & Sesuai \\
\hline & Klik menu hapusgejala & Data gejala terhapus & Sesuai \\
\hline \multirow{3}{*}{3.} & Mengisi form entri solusi dan klik simpan & $\begin{array}{l}\text { Data tersimpan data muncul di } \\
\text { data solusi }\end{array}$ & Sesuai \\
\hline & Klik menu edit solusi & Muncul form edit solusi & Sesuai \\
\hline & Klik menu hapus solusi & Data solusi terhapus & Sesuai \\
\hline \multirow[t]{2}{*}{4.} & Mengisi form entri rule dan klik simpan & $\begin{array}{l}\text { Data tersimpan data muncul di } \\
\text { data rule }\end{array}$ & Sesuai \\
\hline & Klik menu hapus rule & Data rule terhapus & Sesuai \\
\hline \multirow{3}{*}{5.} & Mengisi form entri user dan klik simpan & $\begin{array}{l}\text { Data tersimpan data muncul di } \\
\text { data user }\end{array}$ & Sesuai \\
\hline & Klik menu edit user & Muncul form edit user & Sesuai \\
\hline & Klik menu hapus user & Data user terhapus & Sesuai \\
\hline \multirow[b]{2}{*}{6.} & Klik menu laporan hasil konsultasi user & $\begin{array}{l}\text { Membuka form hasil konsultasi } \\
\text { user }\end{array}$ & Sesuai \\
\hline & Klik menu detail & $\begin{array}{l}\text { Muncul form detail } \\
\text { hasilkonsultasi user danprint } \\
\text { hasilkonsultasi user }\end{array}$ & Sesuai \\
\hline 7. & Klik menu logout & $\begin{array}{l}\text { Kembalike form login } \\
\text { administrator }\end{array}$ & Sesuai \\
\hline
\end{tabular}

Tabel 5.2 Black BoxTesting Halaman User

\begin{tabular}{lllc}
\hline No & Rancangan Proses & Hasil Yang Diharapkan & Hasil \\
\hline 1. & $\begin{array}{l}\text { Mengisi form } \\
\text { registerdankliktombolregister }\end{array}$ & Data tersimpan & Sesuai \\
\hline 2. & $\begin{array}{l}\text { Mengisi form login user dengan } \\
\text { memasukan username dan } \\
\text { password dan klik tombol login }\end{array}$ & Masukhalamanutama user & Sesuai \\
\hline 3. & Klik menu profil user & Muncul form profil pengguna & Sesuai \\
\hline 4. & Klik menu konsultasi & Muncul form konsultasi & Sesuai \\
\hline & Klik menu laporan diagnosa & Muncul form laporan diagnosa & Sesuai \\
\cline { 2 - 4 } 5. & Klik menu detail & $\begin{array}{l}\text { Muncul form detail hasil diagnose } \\
\text { penyakit dan print hasil diagnose } \\
\text { penyakit }\end{array}$ & Sesuai \\
\hline 6. & Klik menu logout & Kembali kehalaman utama semua user & Sesuai \\
\hline
\end{tabular}


DOI: https://doi.org/10.33330/jurteksi.v5i2.344

Available online at http://jurnal.stmikroyal.ac.id/index.php/jurteksi

\section{SIMPULAN}

Berdasarkan uraian yang telah dibahas pada laporan penelitian serta hasil pembahasan dari sistem pakar diagnosa penyakit gigi di Klinik Drg.Tetra Dona Asmira, maka dapat diambil kesimpulan :

1. Sistem pakar diagnosa penyakit gigi ini memberikan manfaat kepada pasien dalam proses melakukan konsultasi.

2. Sistem pakar diagnosa penyakit gigi ini membantu admin dalam mengelola data gejala, solusi, rule dan user.

3. Sistem pakar diagnosa penyakit gigi ini mempermudah asisten dokter untuk mendiagnosa pasien dan membantu dokter untuk mengambil keputusan.

4. Sistem pakar diagnosa penyakit gigi ini bisa digunakan sebagai dokter sementara ketika dokter tidak ada atau belum datang.

\section{DAFTAR PUSTAKA}

[1] Jaenal Arifin. 2016. "Sistem Pakar Diagnosa Penyakit Gigi dan MulutManusia Menggunakan Knowledge Base System dan Certainty Factor", Vol. 10, No. 2:5064.

[2] Joko S. D. R., Damdam D., dan M. Hidayatullah. 2016. "Sistem Pakar Diagnosa Penyakit Lambung dengan
Metode Forward Chaining Berbasis Android", Vol. 6, No. 2:1-8.

[3] Hendra M., Amir H., dan Suraya. 2015. "Pemanfaatan Aplikasi Sistem Pakar Untuk Mendiagnosa Penyakit Gigi dan Mulut Di Klinik Drg.Suyatmi", Vol. 3, No. 1:18-28.

[4] Febrianti, Eka Lia, and Tika Christy. "Peneraan Forward Chaining Untuk Mendianogsa Penyakit Malaria Dan Pencegahanya Berbasis

Web." JURTEKSI $4.1 \quad$ (2017): $93-$ 100. 